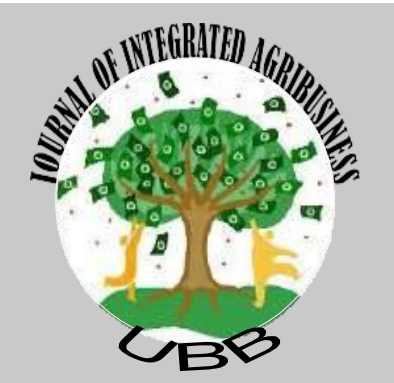

\title{
Journalof IntegratedAgribusiness
}

\section{Website Jurnal : http://jia.ubb.ac.id/ \\ Publikasi Artikel Penelitian}

\section{SERAPAN TENAGA TENAGA KERJA PADA PERUSAHAN PERKEBUNAN KELAPA SAWIT DI DESA MANGKA KECAMATAN BAKAM KABUPATEN BANGKA}

Fera Santikaa, Iwan Setiawan', Evaheldac

abc Jurusan Agribisnis, Fakultas Pertanian Perikanan dan Biologi

Universitas Bangka Belitung, Bangka, Indonesia

Email Korespondensi: ferasantikapurnama@gmail.com

\begin{abstract}
This study aims to describe the uptake of labor in oil palm plantation companies in Mangka Village, Bakam District, Bangka Regency, to analyze what factors influence the level of labor absorption in oil palm plantations in Mangka Village, Bakam District, Bangka Regency. This research was conducted in December 2018 until August 2019 in Mangka Village, Bakam District, Bangka Regency. The research method used was a survey method. The sampling method used was the quota sampling method with a sample of 76 people. Employment uptake in oil palm plantation companies was analyzed using descriptive statistics, while the factors affecting labor absorption were analyzed using multiple linear regression analysis. The results showed that the uptake of labor in oil palm plantation companies in Mangka Village, Bakam District, Bangka Regency over a period of 21 years had increased by $1 \%$. Factors that influence the level of labor absorption in oil palm plantation companies are past labor absorption and education.
\end{abstract}

Keywords: Oil Palm; Absorption Rate; Labor;

\begin{abstract}
Abstrak
Penelitian ini bertujuan untuk mendeskripsikan serapan tenaga kerja pada perusahaan perkebunan kelapa sawit di Desa Mangka Kecamatan Bakam Kabupaten Bangka, menganalisis faktor-faktor apakah yang mempengaruhi tingkat serapan tenaga kerja pada pekebunan kelapa sawit di Desa Mangka Kecamatan Bakam Kabupaten Bangka. Penelitian ini dilaksanakan pada bulan Desember 2018 sampai dengan bulan Agustus 2019 di Desa Mangka Kecamatan Bakam Kabupaten Bangka. Metode penelitian yang digunakan adalah metode survei. Metode penarikan contoh yang digunakan adalah metode quota sampling dengan sampel 76 orang. Serapan tenaga kerja pada perusahaan perkebunan kelapa sawit dianalisis menggunakan statistik deskriptif, sedangkan faktor-faktor yang mempengaruhi srapan tenaga kerja dianalisis menggunakan analisis regresi linear berganda. Hasil penelitian menunjukan bahwa serapan tenaga kerja pada perusahaan perkebunan kelapa sawit di Desa Mangka Kecamatan Bakam Kabupaten Bangka sebesar selama kurun waktu 21 tahun mengalami kenaikan sebesar 1\%. Faktor yang mempengaruhi tingkat serapan tenaga kerja pada perusahaan perkebunan kelapa sawit adalah serapan tenaga kerja dulu dan pendidikan
\end{abstract}

Kata kunci : Kelapa Sawit; Tingkat Serapan; Tenaga Kerja; 


\section{PENDAHULUAN}

Provinsi Kepulauan Bangka Belitung merupakan salah satu provinsi yang memiliki banyak sumber daya yang dapat dikelola terutama dalam sektor produk pertanian dibidang perkebunan yang terkenal dengan produknya yaitu lada putih, kelapa sawit, dan karet. Dari ketiga sektor pertanian ini yang dikelola melalui perkebunan kelapa sawit sangat memberi pengaruh pada perekonomian masyarakat yaitu pada komoditi kelapa sawit. Salah satu provinsi di Indonesia yang memproduksi kelapa sawit adalah Provinsi Kepulauan Bangka Belitung.

Kelapa sawit merupakan salah satu komoditas perkebunan yang memiliki potensi besar dalam meningkatkan petumbuhan ekonomi masyarakat. Perkebunan kelapa sawit umumnya banyak didirikan di daerah perdesaan, sehingga masyarakat memiliki peluang menjadi tenaga kerja di perusahaan perkebunan kelapa sawit tersebut. Menurut BPS (2016), tercatat pada tahun 2015 ada 41 perkebunan besar yang ada di Provinsi Kepulauan Bangka Belitung. Keberadaan perkebunan tersebut tersebar diseluruh kabupaten dengan jumlah yang berbeda. Salah satu kabupaten yang paling banyak memiliki perkebunan besar yaitu Kabupaten Bangka dengan jumlah 10 perkebunan besar. Syahza (2011), menyatakan keberadaan perusahaan dan kegiatan perkebunan kelapa sawit telah memberikan pengaruh yang bersifat positif atau bermanfaat bagi wilayah sekitarnya manfaat tersebut yaitu peningkatan kesejahteraan masyarakat sekitar, memberikan kontribusi terhadap pembangunan daerah dan kesempatan berusaha, serta memperluas lapangan kerja bagi masyarakat petani disekitar.

Salah satu perusahaan perkebunan kelapa sawit yang bergerak di bidang pengolahan dan budidaya yang ada di Kabupaten Bangka berada di Desa Mangka Kecamatan Bakam. Perusahaan perkebunan kelapa sawit tersebut melakukan sistem pengrekrutan tenaga kerja tidak setiap tahun, namun ada waktu-waktu tertentu bagi pihak perusahaan untuk membuka kesempatan kerja bagi masyarakat sekitar melalui informasi yang disebarkan oleh perusahaan melalui website atau browser.

Perminatan tenaga yang diserap oleh perusahaan perkebunan kelapa sawit di Desa Mangka terdiri dari beberapa bagian, antara lain mandor perawatan, pemanenan, dan pengankutan, kontraktor (staf), kondaktor (wakil asisten), asisten (staf), asisten kepala (askep), dan juga manager. Kebutuhan tenaga kerja diimbangi dengan tingkat pendidikan mulai dari Sekolah Dasar (SD), Sekolah Menengah Pertama (SMP), Sekolah Menengah Atas (SMA), Diploma 3 (D3) dan Strata 1 (S1). Semakin tinggi tingkat pendidikan kesempatan kerja semakin beragam, dari bermacam bidang yang dikuasai karyawan upah yang mereka terima pun ikut berbeda.

Menurut Nu'man (2009), perkebunan kelapa sawit memerlukan tenaga kerja yang cukup besar sehingga menjadi salah satu faktor produksi yang menyerap biaya cukup besar sehingga perlu upaya untuk menggunakan sumber daya secara efisiensi untuk menghasilkan hasil seoptimum mungkin, dalam penerapan tenaga kerja terdapat faktor-faktor yang mempengaruhi serapan tenaga kerja di perusahaan perkebunan kelapa sawit. Faktor-faktor tersebut meliputi faktor internal dan faktor eksternal. Faktor internal yang mempengaruhi serapan tenaga kerja penduduk dalam perkebunan kelapa sawit adalah jenis kelamin, pendidikan, umur, dan status sosial. sedangkan faktor ekternal tersebut meliputi lingkungan sosial, lingkungan ekonomi dan karakter inovasi.

Banyaknya tenaga kerja yang bekerja di perkebunan kelapa sawit dapat meningkatkan taraf hidup masyarakat, keberadaan perkebunan kelapa sawit juga dapat mengurangi pengangguran yang terjadi ditengah masyarakat. Akan tetapi, Perusahaan perkebunan kelapa sawit ini tidak setiap tahun membuka lowongan pekerjaan untuk masyarakat sekitar kecuali ada karyawan yang pensiun atau mengundurkan diri. Berdasarkan uraian di atas maka peneliti tertarik untuk melakukan penelitian yang berjudul Serapan Tenaga Kerja di Perkebunan Kelapa Sawit Desa Mangka Kecamatan Bakam Kabupaten Bangka. 
TINJAUAN PUSTAKA

\subsection{Landasan Teori}

Perkebunan merupakan salah satu usaha yanag dilakukan oleh masyarakat Indonesia untuk memenuhi kebutuhan hidupnya. Adapun pengertian macam-macam usaha perkebunan berdasarkan SK. Menteri Pertanian No.325/kpts/Um/1982 adalah sebagai berikut: "Perusahaan perkebunan adalah usaha budi daya tanaman perkebunan yang dilaksanakan diatas lahan Hak Guna Usaha (HGU). Perusahaan perkebunan terdiri dari perkebunan besar dan perkebunan selain perkebunan besar. Perkebunan besar adalah perusahaan perkebunan yang lahannya seluas 25 hektar atau lebih dan diusahakan oleh Badan Hukum Indonesia (BHI). Perkebunan besar dapat dikelola secara sendiri atau bentuk kerja sama yang saling menguntungkan dengan perkebunan rakyat, atau dengan perusahaan perkebunan di luar perkebunan besar dengan pola PIR maupun dengan pola lainnya. Perusahaan perkebunan di luar perkebunan besar dapat diusahakan oleh perseorangan (warga negara Indonesia) atau Badan Hukum Indonesia. Perkebunan rakyat merupakan usaha budidaya tanaman perkebunan yang diusahakan tidak di atas lahan HGU'. Berdasarkan penjelasan di atas jelas bahwa perkebunan terbagi atas 2 macam yaitu:

a. Perkebunan Rakyat

b. Perusahaan Perkebunan

Perbedaan antara kedua perkebunan tersebut adalah terletak pada luas lahan yang digunakan dan pada Hak Guna Usaha (HGU).

\subsubsection{Deskripsi Tanaman Kelapa Sawit (Elaeis Guineensis Jacg)}

Kelapa sawit adalah tanaman perkebunan atau tanaman industri berupa pohon batang lurus dari famili palmae. Tanaman tropis yang berasal dari Amerika ini dikenal sebagai penghasil minyak sayur. Brazil dipercaya sebagai tempat pertama kali kelapa sawit tumbuh. Dari tempat asalnya, tanaman ini menyebar ke Afrika, Amerika Ekuatorial, Asia Tenggara, dan Pasifik Selatan. (Mangoensoekarjo.S, 2003).

Sawit boleh diklasifikasikan kepada tiga jenis bentuk buah berdasarkan ketebalan tempurung, yaitu dura (tempurung tebal), tenera (tempurung tipis) dan pisifera (tiada tempurung). Buah tenera menghasilkan minyak yang lebih banyak berbanding buah dura kerana perbedaan ketebalan tempurung. Pisifera adalah buah betina mandul, yaitu bunga betina yang sepatutnya berkembang untuk menjadi buah dan tandan akan gugur sebelum matang. Keadaan ini menyebabkan pisifera tidak mengeluarkan tandan, sebaliknya banyak mengeluarkan bunga jantan. Namun, ada juga segelintir pisifera yang subur (Syahza. 2002)

Menurut Hartanto (2011), dalam sistem tumbuh-tumbuhan, tanaman kelapa sawit secara ilmiah diklasifikasikan sebagai berikut :

- Divisi : Embryophyta siphonagama

- Kelas : Angiospermae

- Ordo : monocotyledonae

- Famili : Arecaceae (dahulu disebut palmae)

- Sub family: cocoideae

- Genus : Elaeis

- Spesies : E.guineensis.jacg

Secara garis besar tanaman kelapa sawit yang ditanam diIndonesia dibedakan menjadi dua jenis tanaman kelapa sawit yaitu E. Guineensis jenis pertama yang pertama kali dan terluas dibudidayakan orang dan E. Oleifera sekarang mulai dibudidayakan untuk menambah keaneka ragaman sumber daya genetik. 


\subsubsection{Konsepsi Tenaga Kerja}

Tenaga kerja merupakan penduduk yang berada dalam usia kerja. Menurut Peraturan Menteri Tenaga Kerja Dan Transmigrasi Nomor. 7 tahun 2013. Bab I pasal 1 ayat 7 disebutkan bahwa Pekerja/Buruh adalah setiap orang yang bekerja dengan menerima upah atau imbalan dalam bentuk lain. Secara garis besar penduduk suatu negara dibedakan menjadi dua kelompok, yaitu tenaga kerja dan bukan tenaga kerja. Penduduk tergolong tenaga kerja jika penduduk tersebut telah memasuki usia kerja. Batas usia kerja yang berlaku di Indonesia adalah berumur 15 tahun - 64 tahun. Menurut pengertian ini, setiap orang yang mampu bekerja disebut sebagai tenaga kerja. Ada banyak pendapat mengenai usia dari para tenaga kerja ini, ada yang menyebutkan di atas 17 tahun ada pula yang menyebutkan di atas 20 tahun, bahkan ada yang menyebutkan di atas 7 tahun karena anak-anak jalanan sudah termasuk tenaga kerja.

Menurut Supari (2001), Tenaga kerja adalah penduduk yang siap melakukan pekerjaan, penduduk yang telah memasuki usia kerja (working age population):

1. Angkatan kerja adalah penduduk yang berumur 15 sampai dengan 65 tahun yang sedang bekerja atau mencari pekerjaan, Susunan penduduk menurut umurnya dapat dikelompokkan sebagai berikut:

a) Penduduk produktif (usia kerja): umur 15 - 65 tahun

b) Penduduk nonproduktif (dibawah usia kerja): umur 14 tahun kebawah

c) Penduduk nonproduktif (diatas usia kerja : umur 65 tahun keatas

2. Dampak rendahnya kualitas tenaga kerja

Rendahnya kulitas tenaga kerja di Indonesia dapat mengakibatkan banyaknya pengangguran. Pengangguran adalah penduduk usia kerja yang sedang mencari pekerjaan. Orang semacam ini merugikan negara dan secara khusus memberatkan keluarga karena kebutuhan menjadi beban atau tanggungan keluarga yang sudah bekerja. Indikator tingkat beban disebut dependency ratio (DR).

3. Usaha meningkatkan kualitas tenaga kerja di Indonesia

Pada dasarnya ada beberapa upaya peningkatan kualitas kerja, antara lain magang di suatu lembaga-lembaga atau instansi pemerintah maupun swasta, pelatihan-pelatihan atau job training agar mempunyai kesempatan kerja yang baik, belajar di BLK (Balai Latihan Kerja) di suatu daerah atau kota, Kursus-kursus keterampilan, Penataran dan seminar atau lokakarya, menekuni ilmu yang dipelajari untuk meningkatkan kualitas diri dengan menekuni bidang yang diminati, meningkatkan tenaga kerja terampil dengan meningkatkan pendidikan formal maupun informal bagi setiap penduduk.

Menurut Budi (2001), tenaga kerja mencakup penduduk yang sudah atau sedang bekerja, yang sedang mencari pekerjaan dan yang

melakukan kegiatan lain seperti bersekolah dan mengurus rumah tangga. Tenaga kerja dibagi pula kedalam dua kelompok yaitu :

a. Angkatan kerja (laborforce)

Yang termasuk dalam angkatan kerja (laborforce) adalah tenaga kerja atau penduduk usia kerja (15 tahun hingga 65 tahun) yang telah bekerja, atau yang mempunyai pekerjaan namun untuk sementara sedang tidak bekerja, dan yang sedang mencari pekerjaan.

b. Bukan angkatan kerja

Yang termasuk kedalam kelompok bukan angkatan kerja adalah tenaga kerja atau penduduk dalam usia kerja yang tidak bekerja, tidak mempunyai pekerjaan, dan sedang tidak mencari pekerjaan.

Selanjutnya angkatan kerja dibedakan menjadi 2 subsektor yaitu : 
kelompok pekerja dan penganggur.

a. Pekerja

Pekerja adalah orang-orang yang mempunyai pekerjaan, mencakup orang yang mempunyai pekerjaan dan memang sedang bekerja, serta orang-orang yang mempunyai pekerjaan namun untuk sementara waktu kebetulan sedang tidak bekerja.

b. Pengangguran

Pengangguran adalah orang yang tidak mempunyai pekerjaan, lengkapnya orang yang tidak bekerja dan masih mencari pekerjaan. Untuk perbedaan tenaga kerja dan bukan tenaga kerja terletak pada usia. Tenaga kerja adalah penduduk yang berusia lebih dari 15 tahun hingga 65 tahun.

\subsubsection{Jenis-jenis Tenaga Kerja}

Menurut Junandar (2002), jenis-jenis tenaga kerja dibagi menjadi, sebagai berikut:

1. Tenaga Kerja Terdidik

Tenaga kerja terdidik adalah tenaga kerja yang mendapatkan suatu keahlian atau kemahiran pada suatu bidang karena sekolah atau pendidikan formal dan non formal. Contohnya seperti sarjana ekonomi, insinyur, sarjana muda, doktor, master, dan lain sebagainya.

2. Tenaga Kerja Terlatih

Tenaga kerja terlatih adalah tenaga kerja yang memiliki keahlian dalam bidang tertentu yang didapat melalui pengalaman kerja. Keahlian terlatih ini tidak memerlukan pendidikan karena yang dibutuhkan adalah latihan dan melakukannya berulang-ulang sampai bisa dan menguasai pekerjaan tersebut. Contohnya adalah supir, pelayan toko, tukang masak, montir, pelukis, dan lain-lain.

3. Tenaga Kerja Tidak Terdidik dan Tidak Terlatih

Tenaga kerja tidak terdidik dan tidak terlatih adalah tenaga kerja kasar yang hanya mengandalkan tenaga saja.Contoh tenaga kerja model ini seperti kuli, buruh angkut, buruh pabrik, pembantu, tukang becak, dan masih banyak lagi contoh lainnya.

Menurut Hawkins (1999), faktor-faktor yang harus dipertimbangkan dalam peningkatan produktivitas tenaga kerja karyawan, antara lain:

1. Faktor Usia (umur)

Dalam menempatkan tenaga kerja dalam suatu perusahaan harus memperhatikan usia dari tenaga kerjatersebut. Usia dari tenaga kerja perlu disesuaikan dengan pekerjaan yang akan dilakukan. Hal tersebut bertujuanuntuk menghindari rendahnya produktivitas kerja daritenaga kerjayang bersangkutan. Contohnya tenaga kerjapanen dan pemupuk yang berusia lanjut tidak mempunyai tenagayang cukup dalam bekerja dan hanya mampu bekerja dalamskala kecil. Usia tenaga kerja yang produktif berumur 16-64 tahun, sedangkan pada usia 65 keatas sudah dikatakan usia lanjut.

\section{Faktor jumlah tanggungan}

Semakin banyak jumlah tanggungan, makasemakin banyak tekananbagi tenaga kerja untuk membiayai kebutuhan keluarganya. Jumlah tanggungan yang semakin tinggi akan mendorong tenaga kerja bekerja lebih giat dan mendorong produktivitas kerjanya.

3. Faktor prestasi akademis ( tingkat pendidikan)

Tingkat pendidikan dan prestasi akademis yang telah dicapai oleh tenaga kerjaselama mengikuti jenjang pendidikan harus diperhatikan oleh perusahaan, supaya tenaga kerjadapat ditempatkansesuai dengan prestasi akademisnya. Kualitas tenaga kerja yang rendah (pengetahuan dan keterampilan karyawan pemanen dan pemupuk) disebabkan karena kurangnya pendidikan dan pelatihan yang mereka perolehdan menyebabkan produktivitas tenaga kerja yang rendah.

4. Faktor masa kerja

Masa kerja atau pengalaman bekerja pada pekerjaan yangsejenis perlu menjadi pertimbangan perusahaan dalam penempatan tenaga kerja. Semakin lama tenaga kerja bekerja,maka semakin banyak pengalaman yang dimiliki oleh tenaga kerja. Banyaknya pengalaman dalam bekerja 
memberikan tenaga kerjakeahlian dan mendorong tenaga kerja untuk dapat meningkatkan produktivitas kerjanya.

5. Pendapatan Keluarga

Pendapatan keluarga adalah jumlah penghasilan riil dari seluruh anggota rumah tangga yang digunakan untuk memenuhi kebutuhan bersama maupun perseorangan dalam rumah tangga. Pendapatan keluarga merupakan balas karya atau jasa atau imbalan yang diperoleh karena sumbangan yang diberikan dalam kegiatan produksi.

Menurut Soeratno (1996), ukuran pendapatan yang digunakan untuk tingkat kesejahteraan keluarga adalah pendapatan rumah tangga yang diperoleh dari bekerja. Tiap anggota keluarga berusia kerja dirumah tangga akan terdorong bekerja untuk kesejahteraan keluarganya. Beberapa hasil studi menunjukkan bahwa anggota keluarga seperti istri dan anak-anak adalah penyumbang dalam berbagai kegiatan baik dalam pekerjaan rumah tangga maupun mencari nafkah.

Umumnya kepala keluarga penentu utama pendapatan keluarga, namun sebenarnya dalam anggota keluarga lainya juga ikut berperan (Darmawan, 2002)

6. Harapan

Pramita (2008), mengartikan harapan merupakan sesuatu yang dapat dibentuk dan dapat digunakan sebagai langkah untuk perubahan. Perubahan yang menguntungkan dapat menyebabkan individu mencapai hidup yang lebih baik.

7. Pendidikan

Sumarsono (2009), menyatakan bahwa peningkatan kualitas pendidikan mutlak merupakan suatu keharusan dalam mempersiapkan tenaga kerja yang berkualitas dan berdaya saing. Pendidkan pada hakekatnya merupakan proses investasi pengembangan mutu sumber daya manusia dalam bentuk manusia terdidik.

Agar tidak tertinggal dengan masyarakat dan bangsa di dunia, maka peningkatan pendidikan menjadi salah satu sarana untuk meningkatkan potensi dasar yang dimiliki masyarakat dan bangsa Indonesia. Peningkatan kualitas pendidikan akan memiliki makna bagi perbaikan kualitas Indonesia secara keseluruhan (Sumarsono, 2009).

\subsubsection{Konsepsi Kesempatan Kerja}

Menurut Departemen Tenaga Kerja kesempatan kerja adalah lapangan pekerjaan yang tersedia untuk pekerja melalui suatu kegiatan ekonomi produksi. Menurut Fujaya (2002), kesempatan kerja adalah lapangan pekerjaan dan lowongan kerja yang tercipta untuk diisi melalui suatu kegiatan ekonomi (produksi). Kesempatan kerja mencakup lapangan pekerjaan yang sudah diisi dan semua lowongan pekerjaan yang belum diisi. Lowongan pekerjaan mengandung arti adanya kesempatan kerja untuk diisi dan hal ini lazim disebut dengan kebutuhan tenaga kerja.Kesempatan kerja dalam hal ini ditujukan untuk penyerapan tenaga kerja yaitu jumlah tenaga kerja yang diserap atau digunakan dalam satu unit usaha tertentu atau dengan kata lain penyerapan tenaga kerja adalah jumlah tenaga kerja yang bekerja dalam satu unit usaha.

\section{METODOLOGI PENELITIAN}

Penelitian ini dilaksanakan di Desa Mangka Kecamatan Bakam, Kabupaten Bangka. Lokasi penelitian ini ditentukan secara sengaja (purposive) dengan pertimbangan bahwa PT perkebunan sawit beroperasi di Desa Mangka Penelitian ini dilaksanakan pada bulan Desember 2018 sampai dengan bulan Agustus 2019. Metode yang digunakan dalam penelitian ini adalah metode survei. Metode penarikan contoh yang dilakukan dalam penelitian ini menggunakan simple random sampling (sampel acak sederhana). Jumlah responden yang diambil pada penelitian ini yaitu sebanyak 76 orang.

Metode pengumpulan data yang digunakan pada penelitian ini adalah observasi, wawancara, kuisioner, dan studi pustaka. 
Permasalahan yang pertama tentang serapan tenaga kerja pada perusahaan perkebunan kelapa sawit Maka digunakan statistik deskriptif. Model analisis menggunakan statistik deskriptif dalam penelitian ini bertujuan untuk mengetahui serapan tenaga kerja yang meliputi pertumbuhan jumlah anggota keluarga, pertumbuhan angka kelahiran keluarga, dan pertumbuhan sumber penghasilan keluarga, dan ekspektasi bekerja.

Permasalahan kedua yang berkaitan tentang faktor-faktor yang mempengaruhi tingkat serapan tenaga kerja, maka digunakan model Analisis Regresi Linear Berganda dimana sebuah variabel terikat $(\mathrm{Y})$ dihubungkan dengan dua atau lebih variabel bebas $(\mathrm{X})$ untuk mengetahui variabel bebas terhadap variabel terikat. Penggunaan model Analisis Regresi Linear Berganda dimaksudkan untuk membuktikan apakah variabel-variabel seperti pertumbuhan jumlah anggota keluarga, pertumbuhan angka kelahiran keluarga, dan pertumbuhan sumber penghasilan keluarga berpengaruh terhadap tingkat serapan tenaga kerja pada perusahaan kelapa sawit di Desa Mangka Kecamatan Bakam Kabupaten Bangka.

\section{HASIL DAN PEMBAHASAN}

\subsection{Serapan Tenaga Kerja Pada Perusahaan}

\subsubsection{Serapan Tenaga Kerja Berdasarkan Masa Kerja}

Masa kerja merupakan tenggang waktu yang digunakan seorang karyawan untuk menyumbangkan tenaganya pada perusahaan sehingga akan menghasilkan sikap kerja dan ketrampilan kerja yang berkualitas. Semakin lama seseorang bekerja disuatu tempat maka kualitas pekerjaan akan semakin baik kerena masa kerja memberikan pengalaman kerja, pengetahuan dan ketrampilan kerja seorang karyawan. Adapun masa kerja responden pada penelitian ini dapat dilihat pada Tabel 17.

Tabel 17 Serapan Tenaga Kerja Berdasarkan Masa Kerja di Perusahaan Perkebunan Kelapa Sawit

\begin{tabular}{llll}
\hline No & Masa Kerja & Total & Presentase $(\%)$ \\
\hline 1. & $1998-2019$ & 50 Orang & 66 \\
2. & $2009-2019$ & 26 Orang & 34 \\
\hline & Total & 76 Orang & 100 \\
\hline
\end{tabular}

Sumber: Olahan Data Primer 2019

Tabel 17 menjelaskan bahwa masa kerja responden yang bekerja di perusahaan perkebunan kelapa sawit dari tahun 1998-2019 yang masih tetap bekerja hingga saat ini yaitu sebanyak 50 orang atau 66 persen. Sedangkan responden yang bekerja dari tahun 2009-2019 sebanyak 26 orang atau 34 persen.

Pada tabel tersebut dapat disimpulkan bahwa responden yang bekerja dari mulai berdirinya perusahaan perkebunan kelapa sawit lebih banyak dari pada responden yang baru sepuluh tahun bekerja di perusahaan perkebunan kelapa sawit. Berdasarkan wawancara responden karyawan punya alasan tertentu untuk bertahan bekerja di perkebunan kelapa sawit salah satunya karena sulitnya mencari pekerjaan dan sudah merasakan setiap bulan mendapatkan upah/gaji, insentif, THR dan lain-lain. Jika karyawan perusahaan perkebunan kelapa sawit sudah diangkat sebagai karyawan tetap dan dengan usia yang sudah tidak layaklagi bekerja bisa digantikakn posisi dengan anaknya maka inilah yang merupakan salah satu membuat masyarakat berlomba-lombauntuk masuk bekerja di perusahaan perkebunan kelapa sawit.

\subsubsection{Sebaran Responden Berdasarkan Bidang Kerja}

Menurut Malayu (2005) Job Analisis (analisis pekerjaan) adalah menganalisis dan mendesain pekerjaan apa saja yang harus dikerjakan, bagaimana pekerjaannya, dan mengapa pekerjaan itu harus dikerjakan. Jabatan yang diemban oleh seorang karyawan dalam perusahaan sangat berperan 
dalam penentuan responden. Semakin tinggi jabatan yangdimiliki seorang karyawan, maka makin tinggi pengaruh jabatan tersebut terhadap kinerjanya. Adapun sebaran responden berdasarkan bidang kerja dapat dilihat pada Tabel 18.

Tabel 18. Sebaran Responden yang Bekerja di Perkebunan Kelapa Sawit Desa Mangka

\begin{tabular}{|c|c|c|c|}
\hline No & Bidang Kerja & Jumlah (Orang) & Persentase $(\%)$ \\
\hline 1. & Mandor Pemanen & 3 & 7 \\
\hline 2. & Staff Pabrik & 5 & 11 \\
\hline 3. & Karyawan Harian Tetap (KHT) & 5 & 11 \\
\hline 4. & Garuk Piringan & 6 & 13 \\
\hline 5. & Sopir Buah & 6 & 13 \\
\hline 6. & Pemanen Buah & 2 & 4 \\
\hline 7. & Sopir Janjangan Kosong & 1 & 2 \\
\hline 8. & Buruh Harian Lepas (BHL) & 7 & 16 \\
\hline 9. & Karyawan Perkebunan & 5 & 11 \\
\hline 10. & Mandor Janjangan Kosong & 2 & 4 \\
\hline 11. & Satpam Perusahaan & 2 & 4 \\
\hline \multirow[t]{2}{*}{12.} & Operator & 1 & 2 \\
\hline & Jumlah & 45 & 100 \\
\hline
\end{tabular}

Tabel 18 menjelaskan bahwa responden Desa Mangka yang bekerja di perusahaan perkebunan kelapa sawit ada 12 bidang diantaranya mandor pemanen, staff pabrik, karyawan harian tetap (KHT), garuk piringan, sopir buah, pemanen buah, sopir janjangan josong, buruh harian lepas (BHL), karyawan perkebunan, mandor janjangan kosong, satpam perusahaan, dan operator. Bidang kerja yang paling banyak dikerjakan yaitu buruh harian sebanyak 7 orang dengan persentase 16 persen. Buruh harian lepas yaitu semua orang yang bekerja dan terdaftar namanya di perusahaan serta menerima gaji atau upah secara langsung dari perusahaan tempat dia bekerja, baik yang aktif bekerja maupun yang sedang cuti izin dengan perusahaan, sedang mengikuti training, berstatus buruh tetap, kontrak, harian lepas maupun borongan.

Selanjutnya bidang kerja yang paling sedikit tenaga kerja yaitu pada bidang operator. Bidang operator yaitu seseorang yang mengawas semua kerja karyawan sesuai bagian dan divisinya.

Selain responden yang bekerja di perusahaan perkebunan kelapa sawit ada juga sebagian responden yang bekerja diluar perusahaan perkebunan kelapa sawit seperti PNS, pedagang dll. Lebih jelas mengenai responden yang bekerja di luar perusahaan dapat dilihat pada Tabel 19.

Tabel 19. Sebaran Responden yang bekerja di luar perusahaan perkebunan kelapa sawit.

\begin{tabular}{rccr}
\hline No & Bidang Kerja & Jumlah & Persentase \\
\hline 1. & PNS & 3 & 10 \\
2. & Non PNS & 28 & 90 \\
\hline & Total & 31 & 100 \\
\hline
\end{tabular}

Tabel 19 menunjukkan bahwa responden yang bekerja sebagai Pegawai Negri Sipil sebanyak 3 orang atau 10 persen. Sedangkan responden yang bekerja non PNS seperti petani, pedagang, dan lain-lain sebanyak 28 orang atau 90 persen. 


\subsubsection{Sebaran Responden Berdasarkan Penghasilan}

Berdasarkan penggolongannya BPS (Badan Pusat Statistik) tahun 2018 membedakan pendapatan penduduk menjadi empat golongan yaitu:

1. Golongan pendapatan sangat tinggi adalah jika pendapatan rata-rata lebih dari Rp. 3.500 .000 per bulan.

2. Golongan pendapatan tinggiaalah jika pendapatan rata-rata antara Rp. 2.550 .000 sampai Rp. 3.500.000 per bulan.

3. Golongan pendpatan sedang adalah jika pendapatan rata-rata antara Rp. 1.500.000 sampai Rp.2.499.000 per bulan.

4. Golongan pendapatan rendah adalah jika pendapatan rata-rata dibawah Rp. 1.500 .000 per bulan. Komposisi responden berdasarkantingkat pendapatan secara rinci dapat dilihat pada Tabel 20.

Tabel 20. Sebaran Responden Berdasarkan Tingkat Penerimaan Karyawan yang Bekerja di Perusahaan Perkebunan Kelapa Sawit Desa Mangka Tahun 2019

\begin{tabular}{clc}
\hline No & \multicolumn{1}{c}{ Bidang Kerja } & Penghasilan dari perusahaan/bln \\
\hline 1. & Mandor Pemanen & Rp. 3.000 .000 \\
2. & Staff Pabrik & Rp. 3.500 .000 \\
3. & Karyawan Harian Tetap (KHT) & Rp. 2.000 .000 \\
4. & Garuk Piringan & Rp. 1.700 .000 \\
5. & Sopir Buah & Rp. 3.000 .000 \\
6. & Pemanen Buah & Rp. 2.000 .000 \\
7. & Sopir Janjangan Kosong & Rp. 3.000 .000 \\
8. & Buruh Harian Lepas (BHL) & Rp. 2.000 .000 \\
9. & Karyawan Perkebunan & Rp. 2.800 .000 \\
10. & Mandor Janjangan Kosong & Rp. 3.000 .000 \\
11. & Satpam Perusahaan & Rp. 3.000 .000 \\
12. & Operator & Rp. 4.000 .000 \\
\hline
\end{tabular}

Berdasarkan tabel 20 dapat dilihat bahwa responden dominan memiliki pendapatan Rp. 3000.000 sampai dengan Rp. 3.500.000 dengan bermacam bidang pekerjaan seperti mandor pemanen, sopir buah, sopir janjangan kosong, mandor janjangan kosong, satpam perusahaan, dan staff pabrik. Responden dikategorikan memiliki pendapatan dengan golongan tinggi. Pendapatan kerja ditetapkan berdasrkan bidang kerja dan kemampuan masing-masing karyawan. Hal ini sesuai dengan Robbins (2008) kemampuan (ability) adalah kapasitas individu untuk melaksanakan tugas dan pekerjaan tertentu.

\subsection{Faktor-Faktor yang Mempengaruhi Serapan Tenaga Kerja}

\subsubsection{Metode Regresi Linear Berganda}

Model regresi yang digunakan dalam penelitian ini adalah model regresi linear berganda dimana variabel terikatnya (dependent variabel) adalah banyaknya serapan tenaga kerja, sedangkan variabel bebas (independent variabel) adalah pertumbuhan jumlah anggota keluarga $\left(X_{1}\right)$, pertumbuhan angka pernikahan keluarga $\left(X_{2}\right)$, pertumbuhan sumber penghasilan keluarga $\left(X_{3}\right)$, tenaga kerja dulu $\left(\mathrm{X}_{4}\right)$, pendidikan $\left(\mathrm{X}_{5}\right)$, dan ekspektasi kerja $\left(\mathrm{D}_{1}\right)$.

Hasil pendugaan melalui analisis regresi linear berganda terhadap hubungan antara tingkat serapan tenaga kerja sebagai variabel dependen $(Y)$, dengan faktor-faktor input diduga berpengaruh pada tingkat serapan tenaga kerja yaitu pertumbuhan jumlah anggota keluarga $\left(X_{1}\right)$, pertumbuhan angka pernikahan keluarga $\left(X_{2}\right)$, pertumbuhan sumber penghasilan keluarga $\left(X_{3}\right)$, tenaga kerja dulu $\left(\mathrm{X}_{4}\right)$, pendidikan $\left(\mathrm{X}_{5}\right)$, dan ekspektasi kerja $\left(\mathrm{D}_{1}\right)$.

Berdasarkan model (persamaan) regresi linear berganda yang telah diestimasi dapat dilihat 
pada model dibawah ini:

Keterangan:

$Y=\beta_{0}+\beta_{1} X_{1}+\beta_{2} X_{2}+\beta_{3} X_{3}+\beta_{4} X_{4}+\beta_{5} X_{5}+D_{1}$

$\mathrm{Y}=$ Serapan tenaga kerja $(\%)$

$\mathrm{X}_{1}=$ Pertumbuhan jumlah anggota keluarga (orang)

$\mathrm{X}_{2}=$ Pertumbuhan angka pernikahan keluarga (orang)

$\mathrm{X}_{3}=$ pertumbuhan sumber penghasilan keluarga (orang)

$\mathrm{X}_{4}=$ Tenaga Kerja Dulu (orang)

$\mathrm{X}_{5}=$ Pendidikan

$\mathrm{D}_{1}=$ Ekspektasi kerja $(1=$ bekerja di perusahaan perkebunan kelapa sawit lebih terjamin, $0=$ bekerja di tempat lain belum terjamin)

$\beta_{1}, \beta_{2}, \beta_{3}, \beta_{4}, \beta_{5}, D_{1}=$ Koefisien regresi

Berdasarkan persamaan dan nilai-nilai yang ada pada tabel 21, maka didapat persamaan pada tingkat serapan tenaga kerja adalah sebagai berikut:

$\mathrm{Y}=0,084+0,967$ Serapan Tenaga Kerja Dulu + 0,081 Pendidikan

\section{Coefficients ${ }^{a}$}

Tabel 21. Model Persamaan Coefficientsa Serapan Tenaga Kerja Tahun 2019.

\begin{tabular}{|c|c|c|c|c|c|c|c|c|c|}
\hline \multirow{2}{*}{\multicolumn{2}{|c|}{ Model }} & \multicolumn{2}{|c|}{$\begin{array}{l}\text { Unstandardized } \\
\text { Coefficients }\end{array}$} & \multirow{2}{*}{$\begin{array}{l}\begin{array}{c}\text { Standardize } \\
\mathrm{d} \\
\text { Co }\end{array} \\
\frac{\text { afficients }}{\text { Beta }}\end{array}$} & \multirow[t]{2}{*}{$\mathrm{T}$} & \multirow[t]{2}{*}{ Sig. } & \multicolumn{3}{|c|}{ Correlations } \\
\hline & & B & Std. Error & & & & $\begin{array}{l}\text { Zerc- } \\
\text { order }\end{array}$ & Partial & Part \\
\hline \multirow[t]{3}{*}{1} & $($ Constan $\mathrm{t})$ & .048 & .084 & & .570 & .571 & & & \\
\hline & $\begin{array}{l}\text { Serapan_TK } \\
\_1\end{array}$ & .967 & .073 & .844 & 13.204 & .000 & .830 & .840 & .839 \\
\hline & Pendidikan & .081 & .041 & .126 & 1.971 & .052 & .034 & .225 & .125 \\
\hline
\end{tabular}

Sesuai dengan rumusan masalah kedua yaitu faktor-faktor apakah yang mempengaruhi tingkat serapan tenaga kerja pada perkebunan kelapa sawit di Desa Mangka Kecamatan Bakam Kabupaten Bangka akan dianalisis mengggunakan Regresi Linear Berganda dengan menggunakan program aplikasi Komputer yaitu Statistical Product dan Service Solution (SPSS) versi 20. Analisis Regresi Linear Berganda digunakan untuk menganalisis variabel yang signifikan yang mempengaruhi tingkat serapan tenaga kerja yang perlu dilakukan beberapa uji seperti uji klasik dan uji statistika.

Model yang digunakan untuk menjawab rumusan masalah kedua adalah regresi linear berganda. Dimana variabel terikatnya (dependent variabel) adalah tingkat serapan tenaga kerja $\left(\mathrm{Y}_{1}\right)$, sedangkan variabel bebas (independent variabel) adalah pertumbuhan jumlah anggota keluarga $\left(\mathrm{X}_{1}\right)$, pertumbuhan angka pernikahan keluarga $\left(X_{2}\right)$, pertumbuhan sumber penghasilan keluarga $\left(X_{3}\right)$, tenaga kerja dulu $\left(X_{4}\right)$, pendidikan $\left(X_{5}\right)$, dan ekspektasi kerja $\left(D_{1}\right)$.

Hasil dari pendugaan melalui analisis regresi linear berganda terhadap hubungan tingkat serapan tenaga kerja $\left(\mathrm{Y}_{1}\right)$ sebagai variabel dependent dengan faktor-faktor input diduga berpengaruh pada pertumbuhan jumlah anggota keluarga $\left(X_{1}\right)$, pertumbuhan angka pernikahan keluarga $\left(X_{2}\right)$, pertumbuhan sumber penghasilan keluarga $\left(X_{3}\right)$, tenaga kerja dulu $\left(X_{4}\right)$, pendidikan $\left(X_{5}\right)$, dan ekspektasi kerja $\left(D_{1}\right)$. Berdasarkan model (persamaan) regresi linear berganda yang telah diteteapkan pada tingkat serapan tenaga kerja dapat dilihat pada model sebagai berikut:

Keterangan:

$Y=\beta_{0}+\beta_{1} X_{1}+\beta_{2} X_{2}+\beta_{3} X_{3}+\beta_{4} X_{4}+\beta_{5} X_{5}+D_{1}$

(Pers 2) 
$\mathrm{Y}=$ Serapan tenaga kerja $(\%)$

$\mathrm{X}_{1}=$ Pertumbuhan jumlah anggota keluarga (orang)

$\mathrm{X}_{2}=$ Pertumbuhan angka pernikahan keluarga(orang)

$\mathrm{X}_{3}=$ pertumbuhan sumber penghasilan keluarga (orang)

$\mathrm{X}_{4}=$ Tenaga Kerja Dulu (orang)

$\mathrm{X}_{5}=$ Pendidikan

$\mathrm{D}_{1}=$ Ekspektasi kerja $(1=$ bekerja di perusahaan perkebunan kelapa sawit lebih terjamin, $0=$ bekerja

di tempat lain belum terjamin)

$\beta_{1}, \beta_{2}, \beta_{3}, \beta_{4}, \beta_{5}, D_{1}=$ Koefisien regresi

Hasil analisis data menggunakan software SPSS 20.0 diperoleh sebagai berikut pada tabel 22:

Tabel 22. Hasil Analisis Regresi Linear Berganda Serapan Tenaga Kerja di Perusahaan Perkebunan Coefficients ${ }^{a}$

Kelapa Sawit Desa Mangka Kabupaten Bangka

\begin{tabular}{|c|c|c|c|c|c|c|c|c|c|}
\hline \multirow{2}{*}{\multicolumn{2}{|c|}{ Model }} & \multicolumn{2}{|c|}{$\begin{array}{l}\text { Unstandardized } \\
\text { Coefficients }\end{array}$} & \multirow{2}{*}{$\begin{array}{c}\begin{array}{c}\text { Standardize } \\
\mathrm{d} \\
\text { Coefficients }\end{array} \\
\text { Beta }\end{array}$} & \multirow[t]{2}{*}{$\mathrm{T}$} & \multirow[t]{2}{*}{ Sig. } & \multicolumn{3}{|c|}{ Correlations } \\
\hline & & B & Std. Error & & & & $\begin{array}{l}\text { Zerc- } \\
\text { order }\end{array}$ & Partial & Part \\
\hline \multirow[t]{3}{*}{1} & (Constant) & .048 & .084 & & .570 & .571 & & & \\
\hline & $\begin{array}{l}\text { Serapan_TK } \\
\_1\end{array}$ & .967 & .073 & .844 & 13.204 & .000 & .830 & .840 & .839 \\
\hline & Pendidikan & .081 & .041 & .126 & 1.971 & .052 & .034 & .225 & .125 \\
\hline
\end{tabular}

Sumber: Olahan Data, 2019

Berdasarkan tabel 22 diperoleh koefisien untuk variabel $X_{4}=(967) ; X_{5}=(081)$ konstan sebesar 048 sehingga model regresi yang diperoleh adalah $Y=048+967 X_{4}+081 X_{5}$

Keterangan:

$\mathrm{Y}=$ Serapan tenaga kerja $(\%)$

$\mathrm{X}_{4}=$ Tenaga Kerja Dulu (orang)

$\mathrm{X}_{5}=$ Pendidikan

$\mathrm{D}_{1}=$ Ekspektasi kerja $(1=$ bekerja di perusahaan perkebunan kelapa sawit lebih terjamin, $0=$ bekerja

di tempat lain belum terjamin)

$\beta_{1}, \beta_{2}, \beta_{3}, \beta_{4}, \beta_{5}, D_{1}=$ Koefisien regresi

Berdasarkan persamaan linear berganda diatas dapat diartikan dan diambil keputusan sebagai berikut:

1. Konstanta (a)

Ini berarti jika semua variabel bebas memiliki nilai nol (0) maka nilai variabel terikat (Beta) sebesar 0,048 .

2. Tenaga Kerja Dulu $\left(\mathrm{X}_{4}\right)$

Nilai koefisien tenaga kerja dulu untuk variabel $\mathrm{X}_{4}$ sebesar 0,967. Hal ini mengandung arti bahwa setiap kenaikan tenaga kerja dulu satu satuan maka variabel serapan tenaga kerja (Y) akan naik sebesar 967 dengan asumsi bahwa variable bebas yang lain dari model regresi adalah tetap.

3. Pendidikan $\left(\mathrm{X}_{5}\right)$

Nilai koefisien tingkat pendidikan untuk variabel $X_{5}$ sebesar 0,081 . Hal ini mangandung bahwa setiap kenaikan tingkat pendidikan satu satuan maka variabel serapan tenagakerja (Y) akan naik sebesar 081 dengan asumsi bahwa variabel bebasyang lain dari model regresi adalah tetap.

\subsubsection{Uji Multikolinearitas}

Pengujian multikoliniearitas bertujuan untuk menguji ada tidaknya korelasi yang signifikan yang mendekati_sempurna antara variabel independent__ika_antara variabel independent terdapat 
korelasi yang signifikan, maka pada model regresi, linear tersebut terdapat gejala multikoliniearitas. Tabel berikut ini menyajikan hasil pengujian multikoliniearitas.

Tabel 23. Hasil Uji Multikoliniearitas pada Model Regresi Serapan Tenaga Kerja di Perusahaan Coefficients $^{\mathrm{a}}$ Perkebunan Kelapa Sawit Desa Mangka Kabupaten Bangka

\begin{tabular}{|c|c|c|c|c|c|c|c|c|c|}
\hline \multirow[t]{2}{*}{ Model } & & \multicolumn{2}{|c|}{$\begin{array}{l}\text { Unstandardized } \\
\text { Coefficients }\end{array}$} & \multirow{2}{*}{$\begin{array}{c}\begin{array}{c}\text { Standardized } \\
\text { Coefficients }\end{array} \\
\text { Beta } \\
\end{array}$} & \multirow[t]{2}{*}{$\mathrm{T}$} & \multirow[t]{2}{*}{ Sig. } & \multicolumn{3}{|c|}{ Correlations } \\
\hline & & B & Std. Error & & & & Zero-order & Partial & Part \\
\hline & (Constant) & .048 & .084 & & .570 & .571 & & & \\
\hline 1 & Serapan_TK_1 & .967 & .073 & .844 & 13.204 & .000 & .830 & .840 & .839 \\
\hline
\end{tabular}

Sumber: Olahan Data, 2019

bahwa variabel independent yang memiliki nilai tolerance $>0,10$ dan VIP kurang kurang dari 10 dari serapan tenaga kerja dulu (orang) dan pendidikan (tahun). Nilai tolerance masing-masing variabel yaitu, serapan tenaga kerja dulu 0,840 dan pendidikan sebesar 0,125 lebih dari 0,1 berarti tidak ada korelasi antar variabel bebas (independent).

Berdasarkan tabel 23, hasil perhitungan VIF masing-masing variabel yaitu, serapan tenaga kerja dulu sebesar 839, dan pendidikan sebesar 125 kurang dari 10 yang artinya tidak ada korelasi antar variabel bebas (independent).

\subsubsection{Uji Heterokedastisitas}

Uji Heterokedastisitas bertujuan untuk menguji apakah data yang digunakan dalam model regresi terjadi ketidaksamaan variance dari residual satu pengamatan ke pengamatan lain tetap, maka disebut heterokedastisitas. Ada dua cara yang dapat digunakan untuk mendeteksi gejala heterokedastisitas yaitu analisis grafik data analisis statistika sebagai berikut:

a. Analisis Grafik

Gejala heterokedastisitas dapat dilihat dengan menggunakan grafik Scatterplot. Apabila titiktitik data yang terbentuk, tidak membentuk suatu pola atau menyebar,maka model regresi tidak terkena heterokedastisitas. Berikut adalah hasil uji heterokedastisitas menggunakan analisis grafik, dapat dilihat pada gambar dibawah ini:

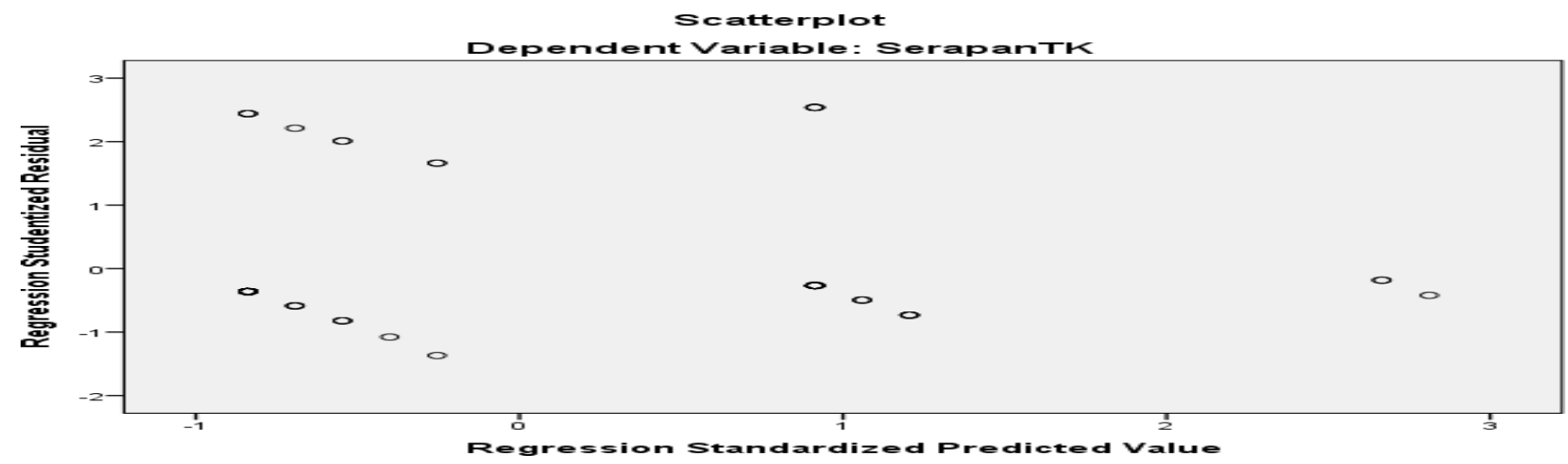

Gambar 2. Hasil Uji Heterokedastisitas Scatterplot

Berdasarkan hasil grafik scatterplots terlihat bahwa titik-titik menyebar tidak banyak baik diatas maupun dibawah angka 0 pada sumbu Y. Hal ini dapat disimpulkan bahwa tidak terjadi heterokedastisitas pada model regresi, sehingga model regresi layak dipakai untuk memperdiksi serapan tenaga kerja perushaan perkebunan kelapa sawit di Desa Mangka Kecamatan Bakam Kabupaten Bangka berdasarkan masukan variabel independent pertumbuhan jumlah anggota keluarga, pertumbuhan angka pernikahan keluarga, pertumbuhan sumber penghasilan keluarga, 
ekspektasi kerja, tenaga kerja dulu, dan pendidikan.

\subsubsection{Uji Autokorelasi}

Uji Autokorelasi bertujuan untuk menguji apakah model regresi linear ada korelasi antara kesalahan pengganggu pada priode t-1 (sebelumnya). Hasil uji autokorelasi dapat dilihat pada tabel 24.

Tabel 24. Hasil Uji Autokorelasi Serapan Tenaga Kerja di Perusahaan Perkebunan Kelapa Sawit Desa Mangka Kabupaten Bangka

\begin{tabular}{|c|c|c|c|c|c|c|c|c|c|c|}
\hline Mo & $\underline{\mathrm{R}}$ & $\underline{R}$ & Adjusted & Std. Error & & Chan & Stat & tics & & Durbin- \\
\hline del & & $\begin{array}{l}\text { Jquar } \\
\text { e }\end{array}$ & R Square & $\begin{array}{l}\text { of the } \\
\text { Estimate }\end{array}$ & $\begin{array}{l}\text { R Square } \\
\text { Change }\end{array}$ & $\begin{array}{c}\text { F } \\
\text { Chang } \\
\text { e }\end{array}$ & df1 & $\mathrm{df} 2$ & $\begin{array}{l}\text { Sig. F } \\
\text { Change }\end{array}$ & Watson \\
\hline 1 & $.840^{a}$ & .705 & .697 & .361 & .705 & 87.315 & 2 & 73 & .000 & 2.015 \\
\hline
\end{tabular}

Model Summaryb

Berdasarkan tabel 24 diatas Uji Durbin-Watson memberikan nilai DW 2.015, nilai ini akan dibandingkan dengan tabel DW dengan jumlah data observasi $(n)=67$, jumlah variabel dependent $(\mathrm{k})=6$ dan tingkat signifikansi 0,00. Oleh karena DW sebesar 2.015 lebih besar dari $+1,55$ dan lebih kecil dari -2,46. Hal ini dapat disimpulkan bahwa model regresi tersebut telah terbebas dari masalah autokorelasi, artinya $\mathrm{H}_{\mathrm{o}}$ diterima dan tidak terjadi autokorelasi.

Arti Angka:

1. Konstanta sebesar 0,048 artinya adalah jika tidak ada perubahan pada serapan tenaga kerja dulu dan tingkat pendidikan, maka rata-rata serapan tenaga kerja adalah sebesar $4,8 \%$.

2. Koefisien regresi sebesar 0,967 artinya adalah jika serapan tenaga kerja dulunya meningkat sebanyak 1 orang, maka serapan tenaga kerja akan meningkat sebesar 96,7\%.

3. Koefisien regresi sebesar 0,081 artinya adalah jika pendidikan kepala keluarga meningkat satu tingkat, maka serapan tenaga kerja akan meningkat sebesar $8,1 \%$.

\subsubsection{Koefisien Regresi}

\subsubsection{Koefisien Determinasi $\left(R^{2}\right)$}

Koefisien determinasi menjelaskan variasi pengaruh variabel-variabel bebas terhadap variabel terikatnya. Atau dapat pula dikatakan sebagai proporsi pengaruh seluruh variabel bebas terhadap variabel terikat. Nilai koefisien dterminasi dapat diukur oleh nilai R-Square atau Adjusted R-Square. R-Square digunakan pada saat variabel bebasnya 1 saja (biasa disebut dengan Regresi Linear Sederhana), sedangkan Adjusted R-Square digunakan pada saat variabel bebas lebih dari satu. Dalam menghitung nilai koefisien determinasi penulis lebih senang menggunakan R-Square dari pada Adjusted R-Square, walaupun variabel bebas lebih dari satu. Hasil uji koefisien determinasi $\left(R^{2}\right)$ pada model regresi tingkat serapan tenaga kerja dapat dilihat pada tabel 25.

Tabel 25. Hasil Uji Koefisien Determinasi (R²) Pada Model Regresi Serapan Tenaga Kerja di

Perusahaan Perkebunan Kelapa Sawit Desa Mangka Kabupaten Bangka

Model Summaryb

\begin{tabular}{|c|c|c|c|c|c|c|c|c|c|c|}
\hline \multirow{2}{*}{$\begin{array}{l}\text { Mo } \\
\text { del }\end{array}$} & \multirow[t]{2}{*}{$\mathrm{R}$} & \multirow{2}{*}{$\begin{array}{c}\mathrm{R} \\
\text { Square }\end{array}$} & \multirow{2}{*}{$\begin{array}{c}\text { Adjuste } \\
\text { d R } \\
\text { Square }\end{array}$} & \multirow{2}{*}{$\begin{array}{c}\text { Std. Error } \\
\text { of the } \\
\text { Estimate }\end{array}$} & \multicolumn{5}{|c|}{ Change Statistics } & \multirow{2}{*}{$\begin{array}{l}\text { Durbin- } \\
\text { Watson }\end{array}$} \\
\hline & & & & & $\begin{array}{l}\text { R Square } \\
\text { Change }\end{array}$ & $\begin{array}{c}\text { F } \\
\text { Chang } \\
\text { e }\end{array}$ & df1 & df2 & $\begin{array}{l}\text { Sig. F } \\
\text { Change }\end{array}$ & \\
\hline 1 & $.840^{a}$ & .705 & .697 & .361 & .705 & 87.315 & 2 & 73 & .000 & 2.015 \\
\hline
\end{tabular}


Sumber: Olahan Data Primer 2019

Dilihat dari tabel diatas hasil output model summary, diketahui nilai kooefisien determinasi ( $R$ Square) 0,840 (nilai 0,948 adalah pengkuadratan darikooefisien korelasi atau $R$, yaitu $(0,840 \times 0,840=$ 0,705). Besarnya angka koefisien determinasi R-Square 0,705 sama dengan 70,5\%. Angka tersebut mengandung arti bahwa Account Recivable Turnover, dan Return On Assets berpengaruh terhadap tingkat serapan tenaga kerja sebesar 70,5\%. Sedangkan sisanya $(100 \%-70,5 \%=29,5 \%)$ dipengaruhi oleh variabel lain diluar model regresi ini.

\subsubsection{Variabel yang Mempengaruhi}

Berikut merupakan hasil uji regresi linear berganda untuk mengkaji hasil analisis faktor-faktor yang mempengaruhi serapan tenaga kerja adalah sebagai berikut:

\subsubsection{Serapan Tenaga Kerja Dulu Terhadap SerapanTenaga Kerja}

Tenaga kerja dulu yaitu banyaknya jumlah anggota keluarga yang bekerja di perusahaan perkebunan kelapa sawit dari tahun 1998 hingga 2009 dengan jumlah sebanyak 77 orang dan hingga sekarang masih aktif bekerja. Setelah dilakukan uji linear berganda, diperoleh hasil bahwa variabel tenaga kerja dulu mempunyai pengaruh secara signifikan terhadap serapan tenaga kerja di Desa Mangka. Nilai signifikansi yang didapat adalah 0,000 nilai lebih kecil dari nilai $a=0,10$. Hasil yang dapat dianalisis dari regresi linear berganda menunjukkan bahwa adanya kecendrungan serapan tenaga kerja dulu dalam serapan tenaga kerja.

\subsubsection{Pendidikan Terhadap SrapanTenaga Kerja}

Pendidikan adalah suatu kegiatan untuk meningkatkan pengetahuaan umum seseorang termasuk di dalam peningkatan penguasaan teori dan keterampilan. Berdasarkan hasil penelitian pendidikan dengan persentase terbesar yaitu SD dengan jumlah 56 orang dengan persentase sebesar 74 persen. hasil ananlisis regresi linear berganda menunjukkan bahwa pendidikan berpegaruh terhadap serapan tenaga kerja. Nilai signifikaninya yaitu sebesar 0,052 lebih kecil dari taraf signifikansi 0,10 sehingga pendidikan terdapat pengaruh terhadap serapan tenaga kerja. Hal ini sejalan dengan penelitian Sumarsono (2009) peningkatan kualitas pendidikan mutlak merupakan suatu keharusan dalam mempersiapkan tenaga kerja yang berkualitas dan berdaya saing. Pendidkan pada hakekatnya merupakan proses investasi pengembangan mutu sumber daya manusia dalam bentuk manusia terdidik.

\subsection{Simpulan}

\section{SIMPULAN DAN SARAN}

Berdasarkan hasil penelitian, maka dapat diambil beberapa kesimpulan sebagai berikut:

1. Serapan teaga kerja di perusahaan perkebunan kelapa sawit rata-rata sebanyak 12 orang selama kurun waktu 21 tahun. Tingkat pertumbuhan tenaga kerja di perusahaan perkebunan kelapa sawit dalam 21 tahun periode (1998-2019) mengalami peningkatan sebesar 1\%.

1. Faktor yang mempengaruhi serapan tenaga kerja pada perusahaan perkebunan kelapa sawit di Desa Mangka Kecamatan Bakam adalah serapan tenaga kerja dulu dan pendidikan mereka mendapatkan bantuan sewa traktor dan excavator, serta dari perusahaan mereka mendapatkan jaminan pemasaran. Selain itu kemitraan KSR juga memberikan keuntungan dari sisi cara manajemen usahatani ubi kayu yang baik sehingga petani yang telah lunas hutangnya tetap bermitra dengan perusahaan inti.

\subsection{Saran}

1. Kepada perusahaan perkebunan kelapa sawit agar membuka lebih banyak lagi peluang kerja bagi masyarakat Desa Mangka untuk bekerja di perkebunan kelapa sawit..

2. Kepada masyarakat untuk lebih ditingkatkan lagi tingkat pendidikannya dan jangan hanya berharap bekerja di perusahaan perkebunan kelapa sawit. 


\section{DAFTAR PUSTAKA}

Akmal, R. 2010. Analisis Faktor-faktor yang Mempengaruhi Penyerapan Tenaga Kerja di Indonesia. Skripsi.

Fakultas Ekonomi Universitas Andalas. Sumatra Barat

Badan Pusat Statistik. 2016. Bangka Dalam Angka. Kabupaten Bangka.

Badan Pusat Statistik. 2018. Provinsi Kepulauan Bangka Belitung dalam Angka. Provinsi Kepulauan Bangka Belitung.

Budi. 2001. Ekologi benih dormansi benih. Makalah. Program Studi Agribisnis Fakultas Pertanian Universitas Sebelas Maret. Surakarta. 20 p.

Chrystiawan. 2016. Analisis Tenaga Kerja Sektoral di Kota Tomohon. Jakarta: Penebar Swadaya Damayanti. 2015. Analisis Perkembangan Penyerapan Tenaga Kerja Pada Perkebunan Besar Kelapa Sawit Kabupaen Naga Raya. Universitas Indonesia, Vol 3, No 22: 158-159

Fauzi, Y, Widyaastuti, Y. E., Setyawibawa, I. Dan Hartono, R. 2006. Kelapa Sawit : Budidaya Pemanfaatan Hasil Dan Limbah, Analisis Usaha Dan Pemasaran. Jakarta : Penebar Swadaya.

Fujaya, Y. 2002. Fisiologi Ikan. Dasar Pengembangan Teknik Perikanan. Rineka Cipta. Jakarta.

Habiburrahman. 2012. Analisis Pengaruh Produk Domestik Regional Bruto Terhadap Penyerapan Tenaga Kerja di Provinsi Lampung. Yogyakarta: Liberti Yogyakarta

Hartono. 2011. Metodologi Penelitian Bisnis: Salah Kaprah dan Pengalaman-pengalaman. BPFE. Yogyakarta. Hawkins. 1999. Penyuluhan Pertanian. Kanisius. Yogyakarta

Juanda, B 2009. Metodologi Penelitian Ekonomi dan Bisnis. Bogor : IPB Press Junandar, U, 2002. Analisis Pendapatan Usahatani dan Pemasaran Industri Kecil Emping Melinjo di Desa Dahu Kecamatan Jiput Kabupaten Pandeglang. [Skripsi]. Bogor : Insitut Pertanian Bogo, Fakultas Pertanian, 2002 Kholidah Azhar,

Zainal Arifin. 2010. Penelitian Pendidikan. Bandung: Remaja Rosda. Malayu (2005). Manajemen Sumber Daya Manusia. Edisi Revisi. Jakarta : Bumi Aksara

Mangoensoekarjo, S. 2003. Manajemen Agrobisnis Kelapa Sawit. Yogyakarta : Universitas Gajah Mada Press.

Indayati (2010). Pengaruh Keterlibatan Karyawan, Budaya Organisasi, dan Gaya Kepemimpinan Terhadap Komitmen Organisasional Dalam Meningkatkan Kinerja Karyawan (Studi Pada Universita Brawijaya). Jurnal Aplikasi Manajemen, Vol. 10 No.2 Hal.344-356 ISSN 1693-5241.

Nazir. 2005. Metode Penelitian. Cetakan Keenam. Bogor: Ghalia Indo. Nawari. 2010. Analisis Regresi dengan MS Excel 2007 dan SPSS 17. Jakarta : PT. Elex Media Komputindo.

Notoatmodjo, S 2007. Promosi Kesehatan dan Ilmu Prilaku. Jakarta : Rineka Cipta.

Ningsih, Suheti. (2015). Pengelolaan Laba Melalui Aktivitas-Aktivitas Rill Peruahaan Perspektif Islam. Iqtishadia, Vol 8, No.1

Nu'man, M. 2009. Pengelolaan Tenaga Kerja Perkebunan Kelapa Sawit (Elaeis guineensis Jacq.) di Perkebunan PT Cipta Futura Plantation, Muara Enim, Sumatera Selatan. Skripsi. Fakultas Pertanian. Institut Pertanian Bogor. Bogor.

Nurmala, T. 2012. Pengantar Ilmu Pertanian. Yogyakarta : Graha Ilmu. Nursalam. 2010. Konsep dan penerapan metodelogi penelitian ilmu keperawatan. Jakarta. Salemba Medika.

Paham. 2008. Filsafat dan Metode Riset. Medan: USU Press.

Pramita, 2008. “The Use Of Urban Public Places IN Jakarta for Adolescents' Hanging Out'. Journal of Asian Architecture and Building Engineering, November 2008/346, 339 - 346.

Priyatno, D. 2010. Paham Analisa Statistik Data dengan SPSS. Yogyakarta : MediaKom.

Profil Desa Mangka, 2018. Profil Desa Mangka. Desa Mangka Kecamatan Bakam Kabupaten Bangka. Robbins, S. 2008. Perilaku Organisasi, Jilid 1 dan 11, alih Bahasa : Hadyana Pujattmaja. Jakarta :

Prenhallindo.

Rizwan, 2005. Faktor-Fktor Yang Mempengaruhi Keputusan Petani Menjadi Peserta Petani Plasma Perkebunan Kelapa Sawit di Desa Sempan Kecamatan Pemali. [skripsi] Sekolah Tinggi Ilmu Pertanian Sungailiat Bangka.

Sugiyono, 2009, Metode Penelitian Kuantitatif, Kualitatif dan RED, Bandung : Alfabeta. 
Sugiyono. 2016. Statistik Untuk Penelitian. Bandung: Alfabeta.

Sumarsono, Sonny. 2009 Ekonomi Sumber Daya Manusia Teori dan Kebijakan Publik. Yogyakarta: Graha Ilmu.

Sumarsono, Sonny. 2003. Ekonomi Manajemen Sumber Daya Manusia dan Ketenagakerjaan. Yogyakarta : Graha Ilmu

Suryanto.2008.Peran Olahraga Senam Diabetes. Dalam jurnal peran olahraga Senam diabetes Dosen Jurusan Pendidikan Kesehatan dan Rekreasi FIK UNY 1,(1),10-11

Syahza, A. 2011. Percepatan Ekonomi Pedesaan Melalui Pembangunan Perkebunan Kelapa Sawit. Jurnal Ekonomi Pembangunan. Volume 12, Nomor 2, Desember 2011, hal 297-310.

Syahza. 2002. Potensi Pembangunan Industri Hilir Kelapa Sawit di Daerah Riau. Usahawan Indonesia, No. 04/TH XXXI April2002, hal 45- 5.Lembaga Manajemen FE UI. Jakarta.

Santoso. 2016. Statistika Hospitalitas. Yogyakarta : Deepublish. Sugiyono 2011. Metode penelitian kuantitatif kualitatif dan RED. Alfabeta Santoso, S, 2014. Statistik Parametrik Edisi Revisi. Jakarta : PT Gramedia.

Supari, D. H. 2001. Manajemen produksi dan operasional agribisnis holtikultura. Kelompok Gramedia, Jakarta.

Sugiyono, 2008. Metode Penelitian Kuantitatif Kualitatif dan RED. Bandung Alfabeta. Sugiyono. 2012. Penelitian Kuantitatif Kualitatif dan RED. Bandung: Alfabeta.

Sulistiyani dan Rosidah, 2009. "Manajemen Sumber Daya Manusia", Yogyakarta : Graha Ilmu.

Umar. 2011. Metode Penelitian untuk Skripsi dan Tesis Bisnis. Bandung: Universitas Komputer Indonesia. 